\title{
ゴルフパッティング動作におけるクラブヘッドの三次元運動計測*
}

\section{Measurement of Three-Dimensional Motion of the Club Head in the Golf Putting Stroke}

\author{
Masaki HOKARI*1, Mayu TSUCHIYA and Satoki MURAI \\ ${ }^{* 1}$ Faculty of Computer Science and Systems Engineering, Okayama Prefectural University \\ 111, Kuboki, Soja, Okayama, 719-1197, Japan
}

This study describes a method for measurement of the golf putting stroke. The data obtained can be available for sports skills assessment and training. Measurement method proposed was derived by kinematical human body model analysis. The system was developed using 3-D gyro sensor and infrared sensor. Gyro sensor was used to measure the rotation of the club head. Moreover, infrared sensor was used to measure the distance changes between the grip end and the body during putting stroke. As a result of the experiment, the following matter became clear. (1) During swing, since the distance of grip end and body of subjects is changing, it cannot be said that putting stroke is a simple pendulum easily. (2) The golf middle-class player swung so that the face side of a head might become perpendicular to the direction of a hit ball. Finally, the data obtained by this system showed that the quantitative evaluation of some technical standards expressed in a famous golf lesson textbook could be carried out.

Key Words : Kinematics, Measurement, Sports Engineering, Sports Biomechanics, Golf Putting Stroke

\section{1.は じめ に}

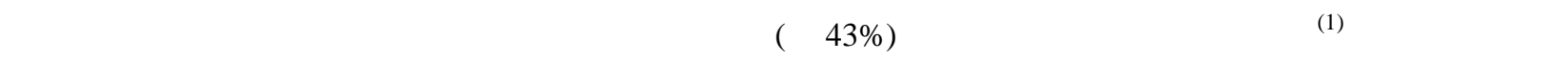
の的確な状況判断, 正確なパッティング動作といったパットスキルを向上させ , パット数を少なくすることができ ればスコアの向上に直接結びつく．しかし，一般のゴルファーの多くは，他のクラブに比べてパターの練習に費 やす時間は少ないのか現状である .この理由として , パットの練習設備のある練習場が少ないことやパットの重 要性に気付いていないゴルファーが多いこと, ダイナミックなスイングをするドライバーやアイアンに注目が集 まっていること，などが挙げられる．

パットの練習機器として一般的な人工芝のマットの先にカップの付いている機器では, パッティング動作の良し 悪しの判断がゴルファー自身に委ねられるため, 平均的なレベルのゴルファーがこれを判断することは困難であ る.このように，練習時のパッティング動作の質に関する正確なフィードバックが行われないことが，パットス キルの向上を妨げる要因となっている ${ }^{(2)(3)}$. クラブヘッドの運動，すなわちパッティング動作が定量化でき，パッ トスキルやカップインとの関係も定量化できれば，光の結果を練習にフィードバックすることで練習の効率が向 上する . 定量化のために , パッティング動作の計測方法とシステムが重要である . パッティング動作やパターク ラブに関する多くの研究では, DLT 法がよく用いられている ${ }^{(4)}$ (9). この方法では 2 台以上のビデオカメラを用い て高い精度でヒトのパッティング動作やクラブの運動を計測できる . しかし, 複数台の同期の取れるビデオカメ ラを空間に設置する必要があり，空間的にもシステム構成的にも規模が大きくなり，高コストとなる．光のため， 一般のゴルファーが練習時に活用することはできない . また，ゴルファーの回転運動やビデオカメラの設置位置 により画像中のマーカーか隠れてしまうことがあり，クラブヘッドやシャフトのように細く小さい部分の回転運動

* 原稿受付 2013 年 4 月 17 日

*1 正員, 岡山県立大学情報工学部（†719-1197 岡山県総社市窪木 111）

*2 学生員, 岡山県立大学大学院情報系工学研究科

E-mail: mhokari@ss.oka-pu.ac.jp 


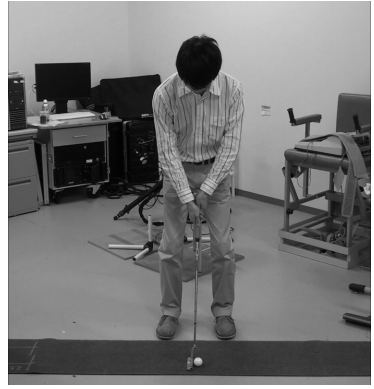

(a) Adress

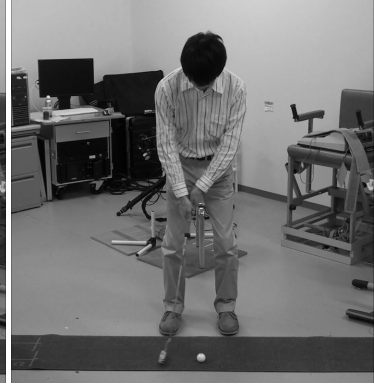

(b) Back swing

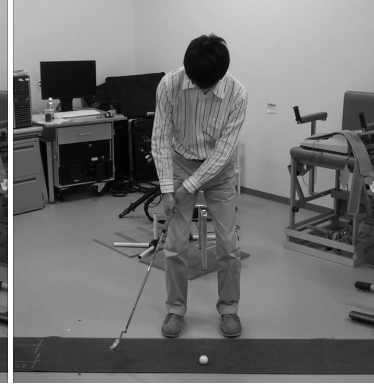

(c) Top of swing

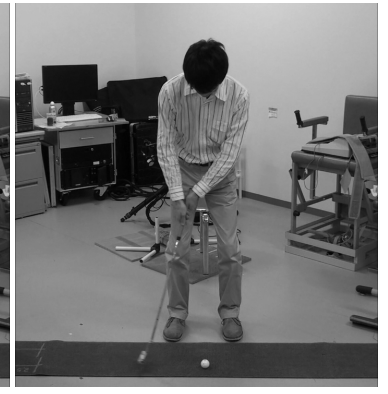

(d) Down swing

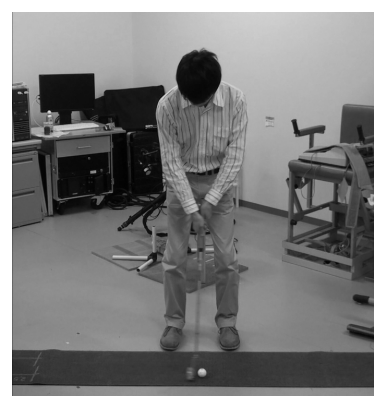

(e) Impact

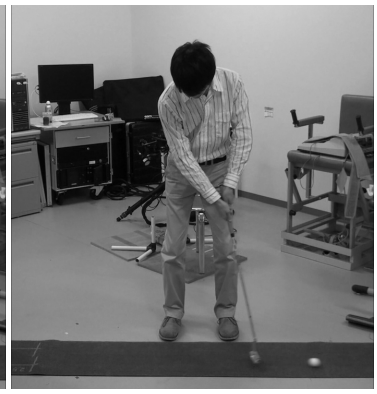

(f) Follow through

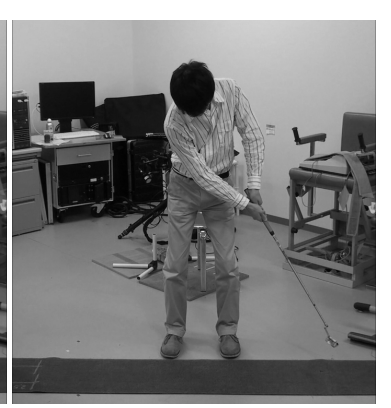

(g) Finish

Fig. 1 Golf putter swing

は画像の分解能から高い精度で計測できないことがある .一方，MEMS(Micro Electro Mechanical Systems) 技術の 進歩により, ジャイロセンサや加速度センサなどの小型化, 軽量化かつローコスト化が進み , これらのセンサで構 成される慣性センサユニットが普及しつつある . スポーツ分野においてもこのセンサユニットは導入されている . ゴルフでは無線タイプのユニットを使用して , パッティング動作中のヘッドの運動解析に使用されている(10).$し$ かし, ユニットをシャフトへ取り付けるためのグリップ部の改造が必要で, ユニット内蔵型パターの使用場所が 限定される恐れがある．

本研究の最終目標は, 室内用パッティング練習システムの構築である. 兴の第一段階として，本論ではジャイ ロセンサと赤外線センサを使用した三次元空間内におけるパッティング動作時のクラブヘッド運動の計測方法を 提案し, 弚のシステム化について取り組む . 計測で使用するセンサ類は, シャフトのグリップ部の改造を行わず， 容易にシャフトへの取り付けが可能である.さらに，提案したシステムを用いて，言語表現されたパットスキル の定量化の可能性について検討する .

\section{2. パッティング動作}

ドライバーやアイアンを使用したスイング(11) (14)に比べて , パターを使用したスイングはクラブの姿勢变化や 移動距離，身体の動きが少ない単純な動作である ${ }^{(15)}$.

図 1 にアドレスからフィニッシュまでの一連のパッティング動作を分解図で示す．(a) アドレスではパターを目 標に向け , スイングの構えで静止している . (a) アドレスから (b) バックスイングにかけて , 腰や下肢はほとんど動 かさず, 手, 前腕, 上腕，肩が同時に動く．このとき，上肢はアドレス静止時における左右肩関節，左右肘関節， 左右手関節の各関節角度を保つように, 脊柱を中心にして回転する .これより，パッティング動作は単振子に例 えられる ${ }^{(1)}$. しかし , 一連のスイング動作において各関節角度は变化する恐れがあり, クラブヘッドと回転中心と の長さが変化する可能性がある . 次に , (c) トップオブスイングではクラブのテークバックが最大となる . (c) トッ プオブスイングから (d) ダウンスイングにかけては , (a) アドレスから (b) バックスイングにかけてと逆の回転を する . (e) インパクトの瞬間は , 身体各部位やパターの位置が (a) アドレスとほぼ同じとなる . (f) フォロースルー， (g) フィニッシュに至る. (g) フィニッシュでは数秒間姿勢を維持することが多い . 


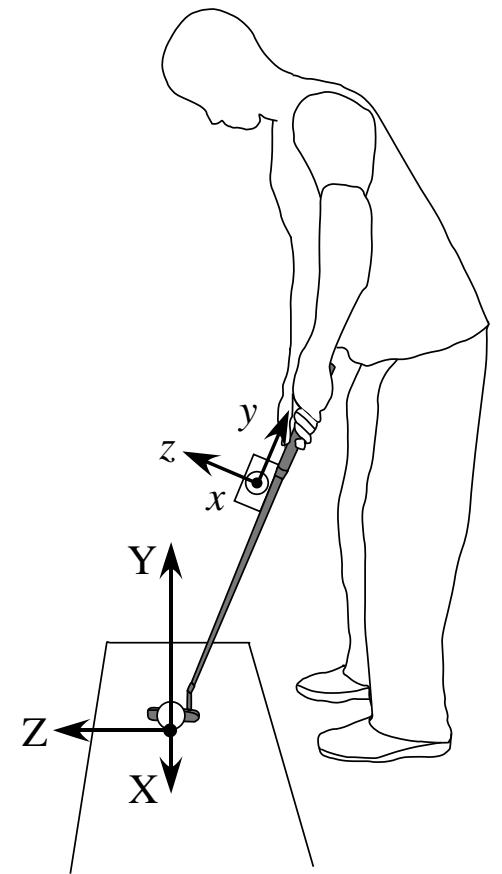

Fig. 2 The definition of coordinate system

\section{3. 解 析 方 法}

\section{$3 \cdot 1$ 座標系の定義}

図 2 で示す X-Y-Z 絶対座標系およびパターシャフト上の x-y-z 相対座標系でパッティング動作時のクラブヘッド の回転運動と移動軌跡を考える .

絶対座標系は静止したボールと地面との接点を原点とし，ボールの打ち出される水平方向を X 軸正方向，鉛直 上方を $\mathrm{Y}$ 軸正方向，ゴルファー正面の水平方向を Z 軸正方向とする．一方，相対座標系はパターシャフト上に定 義し, シャフトのヘッドからグリップ方向を $\mathrm{y}$ 軸正方向, 弚机に直交しパターのフェース面の向いている方向を $\mathrm{x}$ 軸正方向， $\mathrm{x}$ 軸と $\mathrm{y}$ 軸の外積方向を $\mathrm{z}$ 軸正方向とする．どちらの座標系も右手系であり，回転方向は右ねじの方向 を正とする．

\section{$3 \cdot 2$ パッティングモデル}

パッティングモデルを図 3 に表す.シャフト延長線がゴルファーの身体と接触する点を点 $\mathrm{A}$ とし，弚こを原点 とする x-y-z 相対座標系を考える . パッティングはアドレス静止時に形成される左右肩関節, 左右肘関節, 左右手 関節で構成される五角形または三角形を維持し, グリップエンドは常に脊䯣に向いているため, 脊髄を回転軸とし た振り子運動とみなすことができる ${ }^{(1)}$. しかし , クラブヘッドの中心からゴルファーの脊髄までとする振り子の長 さには, シャフト延長線とゴルファーの脊髄を結んだ線上にある身体との接触点 (腹部) と, 脊䯣までの距離が含 まれている .この距離は医用画像診断装置を用いて計測しなければならないため, 実験システムの構成規模が大 きく高コストとなり，実用的なシステムの構築は困難である .さらに , ゴルファーは , スイングに集中しているた め, 接触点 (腹部) と脊髄との距離か変化するような腹式呼吸を行っていないと考える. 以上より，アドレスした 際のシャフト延長線とゴルファーの脊髄を結んだ線上にある身体との接触点 (腹部)を相対座標系の原点と定めた .

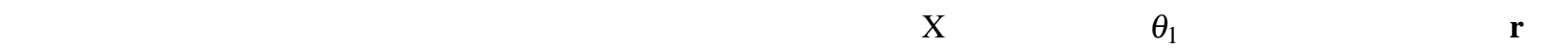
記述されるとする．また，相対座標系の原点 $\mathrm{A}$ は絶対座標系の原点 $\mathrm{O}$ から距離 $l(t)$ だけ離れていて，絶対座標系 から点 A の位置を表すべクトルを $\mathbf{p}_{a}$ とする . 相対座標系においてべクトル $\mathbf{p}_{b}$ が与えられたとき，絶対座標系か ら見たベクトル $\mathbf{p}_{b}$ の先端の座標を表すべクトルを $\mathbf{p}$ とすると, $\mathbf{p}_{b}$ は点 $\mathrm{A}$ を支点とし, 時間とともに変化する長 


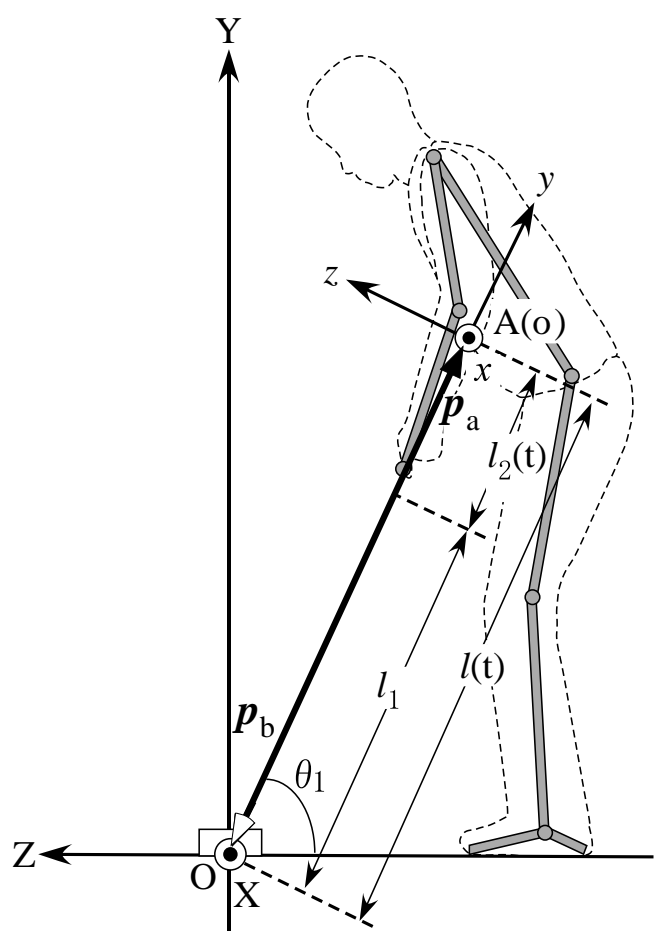

Fig. 3 Approximate link model of putter swing

さ $l(t)$ の振り子を表し, $\mathbf{p}$ はクラブヘッドの座標を表す . このとき, ベクトル $\mathbf{p}$ は次のように求まる .

$$
\mathbf{p}=\mathbf{r} \cdot \mathbf{p}_{b}+\mathbf{p}_{a}
$$

式(1)よりアドレス時のクラブヘッドの座標か浗まる. 実際には右辺第 1 項にオイラー変換を適用することで, 時々 刻々と変化するクラブヘッドの座標を求めることができる．

次に, 絶対座標系における具体的なクラブヘッドの三次元座標值を求める . 図 3 のモデルは, アドレスした際 のパターシャフトからの延長線がゴルファーの身体と接触する点 $\mathrm{A}$ とし , 兴の点 A からからクラブヘッドまで の長さ $l(\mathrm{t})$ の振り子としてパターの運動を表す .ここで , パターの長さを $l_{1}$ とする .さらに , パターのグリップ エンドから身体に接する点までの長さは時間とともに変化すると仮定し，弚の長さを $l_{2}(t)$ とする．これらより， $l(t)=l_{1}+l_{2}(t)$ と表せる . パターシャフトと Z 軸のなす初期角を $\theta_{1}$ とする . 絶対座標系から点 A の位置を表すべ クトル $\mathbf{p}_{a}$ と x-y-z 相対座標系からみたクラブヘッドの位置を表すべクトル $\mathbf{p}_{b}$ は , 次のようになる .

$$
\mathbf{p}_{\mathbf{a}}=\left(\begin{array}{c}
0 \\
l(t) \sin \theta_{1} \\
-l(t) \cos \theta_{1}
\end{array}\right), \mathbf{p}_{\mathbf{b}}=\left(\begin{array}{c}
0 \\
-l(t) \\
0
\end{array}\right)
$$

相対座標系は絶対座標系に対し，X軸周りで右ねじの向きにー $\left(90-\theta_{1}\right) \operatorname{deg}$ だけ回転している . この回転を表す回 転行列 $\mathbf{r}$ は次のようになる .

$$
\mathbf{r}=\left(\begin{array}{ccc}
1 & 0 & 0 \\
0 \cos \left(-\left(90-\theta_{1}\right)\right) & -\sin \left(-\left(90-\theta_{1}\right)\right) \\
0 \sin \left(-\left(90-\theta_{1}\right)\right) & \cos \left(-\left(90-\theta_{1}\right)\right)
\end{array}\right)
$$

図 2 に示す $\mathrm{x}-\mathrm{y}-\mathrm{z}$ 相対座標系におけるパターシャフトの $\mathrm{x}$ 軸, $\mathrm{y}$ 軸, $\mathrm{z}$ 軸周りの回転角度は, 図 3 の $\mathrm{x}-\mathrm{y}-\mathrm{z}$ 相対 座標系の各軸の回転角度として考えることができる . パターが $\mathrm{x}$ 軸 , $\mathrm{y}$ 軸, $\mathrm{z}$ 軸周りにオイラー角 $\theta_{x}(t), \theta_{y}(t)$, $\theta_{z}(t)$ だけ回転したとする . 軸の回転順序によって最終的なパターの姿勢が異なることがあるため, 本研究では才 イラー角のいくつかの表現法を試し，運動を最もよく近似できた z-y-x オイラー角を用いる . この回転行列は次 のようになる . 


$$
\mathbf{R}\left(\theta_{z}(t), \theta_{y}(t), \theta_{x}(t)\right)=\left(\begin{array}{ccc}
1 & 0 & 0 \\
0 \cos \theta_{x}(t) & -\sin \theta_{x}(t) \\
0 \sin \theta_{x}(t) & \cos \theta_{x}(t)
\end{array}\right) \cdot\left(\begin{array}{ccc}
\cos \theta_{y}(t) & 0 \sin \theta_{y}(t) \\
0 & 1 & 0 \\
-\sin \theta_{y}(t) & 0 \cos \theta_{y}(t)
\end{array}\right) \cdot\left(\begin{array}{ccc}
\cos \theta_{z}(t)-\sin \theta_{z}(t) & 0 \\
\sin \theta_{z}(t) & \cos \theta_{z}(t) & 0 \\
0 & 0 & 1
\end{array}\right)
$$

絶対座標系から見たクラブヘッドの座標を $\mathbf{p}(t)$ とし，次のように定義する .

$$
\mathbf{p}(t)=\left(\begin{array}{c}
x(t) \\
y(t) \\
z(t)
\end{array}\right)
$$

以上より，ある時刻 $t$ におけるクラブヘッドの絶対三次元座標值は以下のようになる .

$$
\mathbf{p}(t)=\mathbf{R}\left(\theta_{z}(t), \theta_{y}(t), \theta_{x}(t)\right) \cdot \mathbf{r} \cdot \mathbf{p}_{\mathbf{b}}+\mathbf{p}_{\mathbf{a}}
$$

上式よりクラブヘッドか時間とともに絶対座標系上でどのように運動するか推定できる .

\section{4. 実験システム}

\section{$4 \cdot 1$ 実験方法}

絶対座標系におけるヘッドの運動を求めるために, 以下の計測が必要である .

(1) アドレス時のパターシャフトの延長線とゴルファーの身体が接触する点 A からクラブヘッドまでの長さ $l(t)$

(2) 絶対座標系のX 軸とパターのなす初期角度 $\theta_{1}$

(3) 図 3 に示すゴルファーの体幹上に設定した相対座標軸周りの角速度 $\left(\omega_{x}(t), \omega_{y}(t), \omega_{z}(t)\right)$ と角度 $\left(\theta_{x}(t), \theta_{y}(t)\right.$, $\left.\theta_{z}(t)\right)$

(1) の $l(t)$ はパターの長さ $l_{1}$ を定規で , パターシャフトに沿ってグリップエンドから身体に接するまでの長さ $l_{2}(t)$ を赤外線センサで計測する . (2)の $\theta_{1}$ は傾斜計でアドレス時のパターシャフトと地面のなす角を計測するこ とで求まる . (3) の角速度と角度は図 3 に示す x-y-z 相対座標系の各軸周りの角速度 $\left(\omega_{x}(t), \omega_{y}(t), \omega_{z}(t)\right)$ をジャ イロセンサで計測し，产の結果を時間積分することで角度 $\left(\theta_{x}(t), \theta_{y}(t), \theta_{z}(t)\right)$ を求める。

クラブヘッドの三次元運動を計測するための実験システムを図 4 に示す . このシステムは次の 5 要素から構成 される .

(a) 三次元ジャイロセンサ : (株) 村田製作所 ENC-03R の小型圧電振動ジャイロを三次元直交配列したセンサユ ニット (寸法 : $4 \mathrm{~cm} \times 3 \mathrm{~cm} \times 2 \mathrm{~cm}$ ) をパターシャフト上に取り付け，回転角速度を計測する . ジャイロは長時間 使用するとドリフトが生じる . 本研究の対象スイングであるパッティング動作の計測時間範囲では, ドリフ トによる影響はほとんどない，実際に，静止状態をジャイロセンサで 10 秒間計測した結果の一例を図 5 に示 す . 時間が経過することで, ドリフトによる電圧変化が見られる .しかし, 10 回の計測を行い, 各軸周りの ドリフトの最大值の平均を求めたところ, $\mathrm{x}$ 軸周り $0.2 \mathrm{deg}, \mathrm{y}$ 軸周り $0.1 \mathrm{deg}, \mathrm{z}$ 軸周り $0.3 \mathrm{deg}$ 程度であった .

(b) 赤外線センサ : (株) シャープの GP2Y0A21YK0F をグリップエンドに取り付け, グリップエンドから身体に接 するまでの長さ $l_{2}(t)$ を計測する . 赤外線センサの出力電圧 $\mathrm{V}$ と距離 $l_{2}(t)$ との校正曲線を図 6 に示す . 次式 より, 長さ $l_{2}(t)$ を求める.

$$
l_{2}(t)=4.88 V^{4}-34.74 V^{3}+96.31 V^{2}-131.26 V+88.72
$$

(c) インパクト検出センサ : インパクトによってボール位置が変化し, (b) と同じセンサの出力が大きく変化する ことを利用してインパクト時刻を検出する．

(d) ビデオカメラ (三次元動作解析システム用) : 絶対座標 $(400 \mathrm{~cm}, 66 \mathrm{~cm}, 0 \mathrm{~cm})$ と $(0 \mathrm{~cm}, 66 \mathrm{~cm}, 400 \mathrm{~cm})$ にビ デオカメラ (JVC ケンウッド (株)，GZ-E345) を設置してパッティング動作中のクラブの運動を 60fps で撮影 する.この撮影映像にDLT 法を適用し，弚の結果から求まるクラブヘッドの三次元座標と本論の提案手法で 


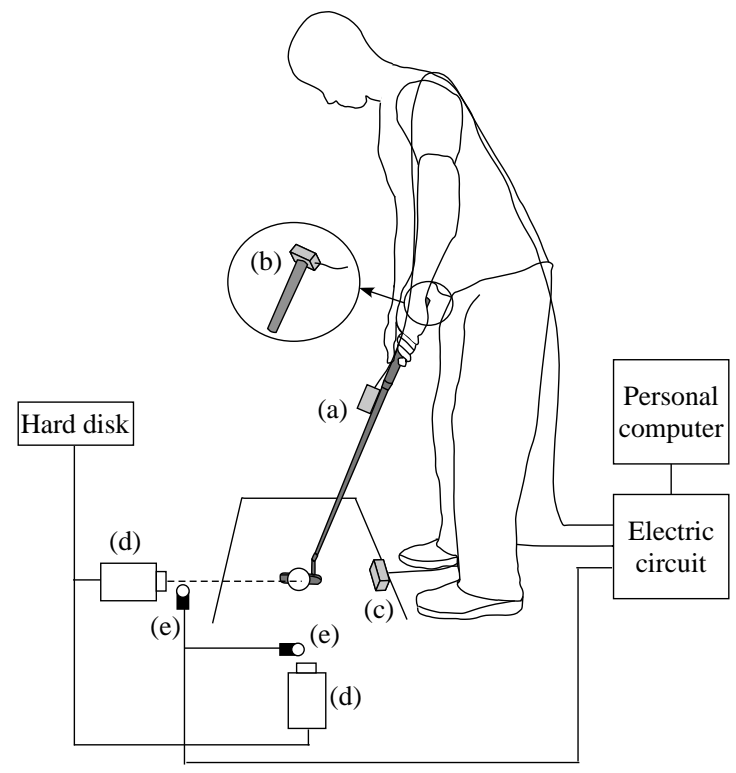

(a) 3D gyro sensor

(b) Infrared sensor

(c) Infrared sensor for impact timing

(d) Video camera

(e) LED

Fig. 4 Experimental system

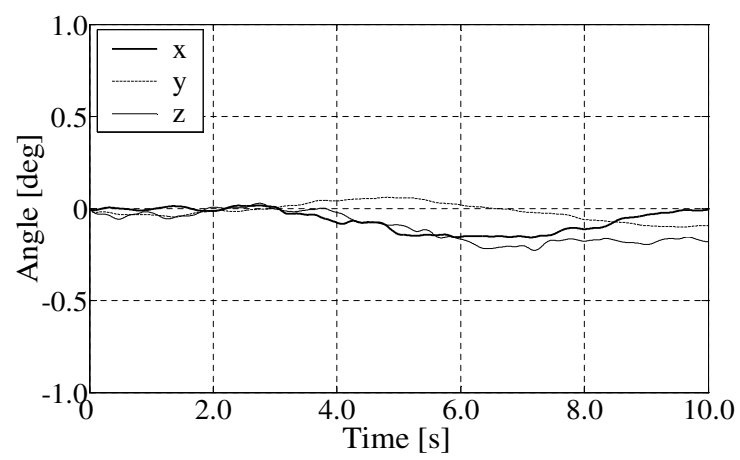

Fig. 5 The drift evaluation of 3-D gyro sensor

求まるクラブヘッドの三次元座標を比較する .なお, DLT 法は三次元の動作解析システム Ariel Performance Analysis System (APAS) を使用する .ヘッドフェースの中心に撮影用マーカを取り付けると，インパクト付近 ではマーカがボールで隠れ，撮影できない，弚のために，クラブのネック部にマーカを取り付けた .ヘッド の変位および軌跡では, ヘッド中心からみたネックの位置 (座標) 情報を組み込んで計算されている .

(e) 発光ダイオード (LED) : 計測開始時に点灯させることにより，センサ側には電圧で，ビデオカメラ側には光 で , 映像とセンサ出力の同期開始点を示す.

図 7 に信号処理システムを示す. 各センサの出力はサンプリング周波数 $100 \mathrm{~Hz}$, データ点数 1024 で $\mathrm{AD}$ 変換 (CONTEC 社製 AD 変換ボード PCA68PS-1.5P) して PC に取り込み, $3 \mathrm{~Hz}$ のデジタルローパスフィルタでノイズを 除去する.三次元ジャイロセンサの出力である角速度を数值積分することにより，図 3 の x-y-z 相対座標系に対応 する各軸周りの角度を求める. この角度とパターの長さ $l_{1}$, (b) の赤外線センサで計測した $l_{2}(\mathrm{t})$, 絶対座標系の $\mathrm{X}$ 軸とパターのなす初期角度 $\theta_{1}$ を式 (2)に代入し，絶対座標系におけるへッドの三次元座標を求める． 


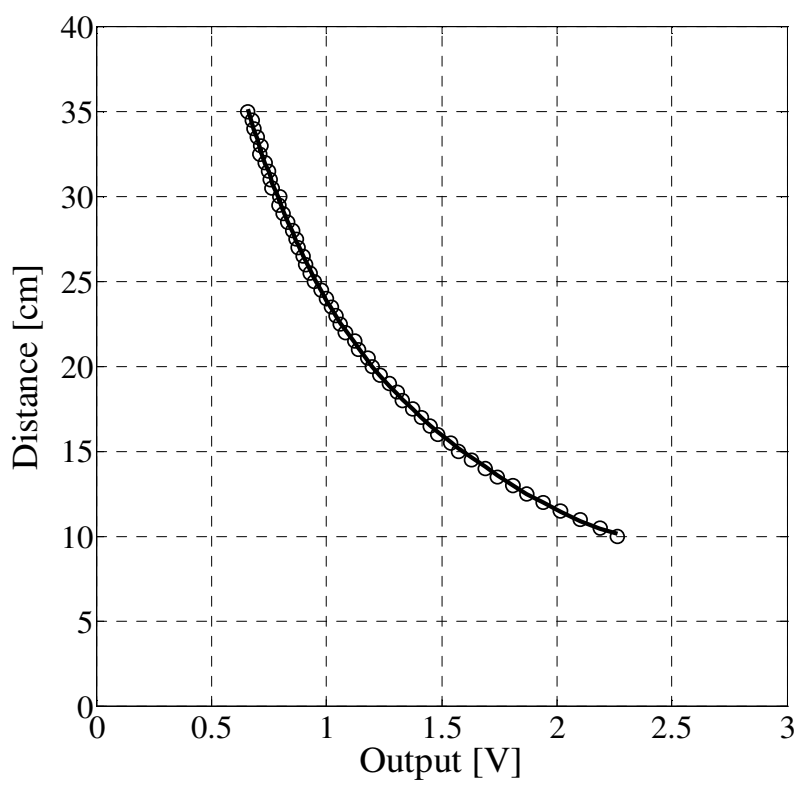

Fig. 6 The calibration curve of infrared sensor

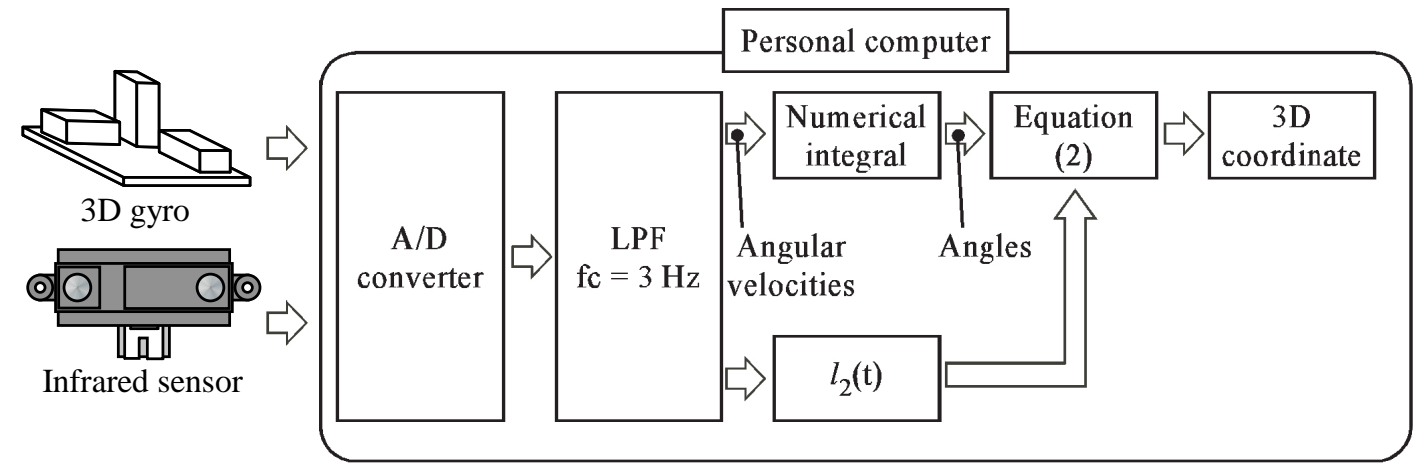

Fig. 7 Signal proccessing

Table 1 The attributes of examinees

\begin{tabular}{c|c|c}
\hline Attributes & Middle player & Novice player \\
\hline Age & 22 & 22 \\
\hline Height $[\mathrm{cm}]$ & 173.0 & 170.0 \\
\hline Weight $[\mathrm{kg}]$ & 67.0 & 60.0 \\
\hline
\end{tabular}

\section{$4 \cdot 2$ 実験条件}

被験者は, 表 1 の特性を持つ大学生の右打ちの 2 名で, 経験者 1 名, 未経験者 1 名とした . 被験者の使用する パター (US Athletes 社製) およびボール (Z-UR SRI スポーツ社製) は同一のものとした . パターはピン型と呼ばれ る形状をしたクラブヘッドであり，プロゴルファーからアマチュアゴルファーの間で広く使用されている種類の パターである．室内に図 8 に示すパターマットを設置し，ボールからカップまでの距離を $300 \mathrm{~cm}$ とした . ボール と芝が接する位置から $3 \mathrm{~cm}$ に絶対座標系 X 軸と直交し，Z軸と平行となるようにマーカーを設置し，アドレス時， 光のマーカーにクラブヘッドを置くよう被験者へ教示した．この位置とヘッドの寸法より，ヘッド中心の初期座標 は $(-3 \mathrm{~cm}, 2.5 \mathrm{~cm}, 0 \mathrm{~cm})$ となる.被験者は数回練習を行った後 , パターの三次元回転運動の計測を連続して 10 回行っ た . 実験者の動作開始の合図で被験者はパッティング動作を開始し，計測終了の合図があるまで，フィニッシュ の姿勢を維持するように指示した . 各試行前に, アドレスした状態を維持させ , 図 3 の角度 $\theta_{1}$ を傾斜計で計測し た . シャフトに沿ってグリップエンドから身体に接するまでの長さ $l_{2}(t)$ をグリップエンドに装着した赤外線セン サで計測するために, 被験者の腹部に反射体 (マーカー) を取り付けた . 


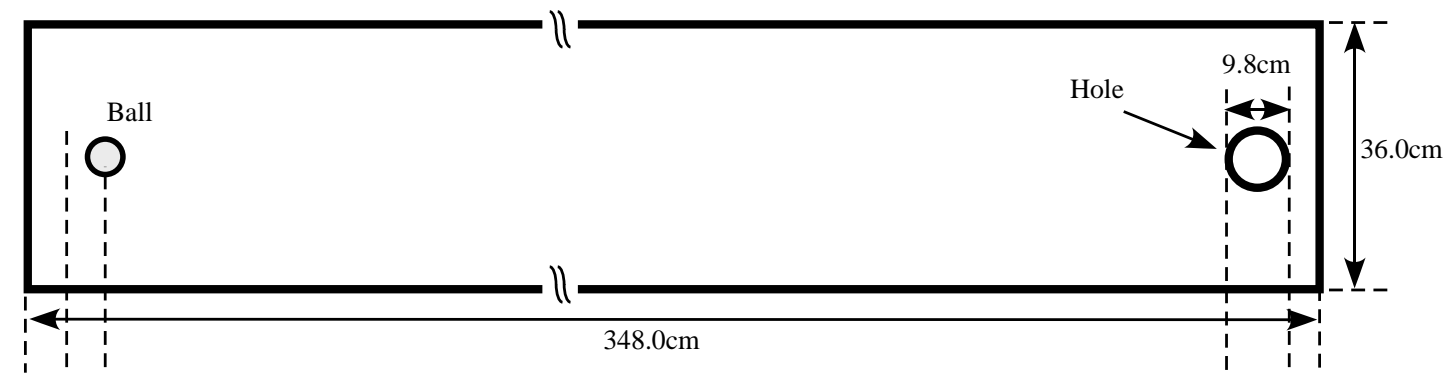

(a) Top of view

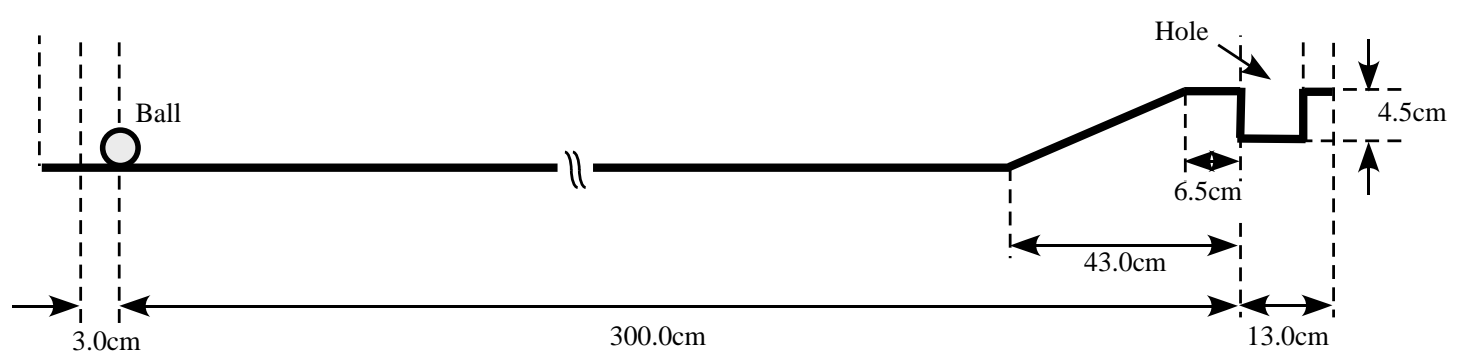

(b) Front of view

Fig. 8 The calibration curve of the output voltage of an infrared sensor and the distance

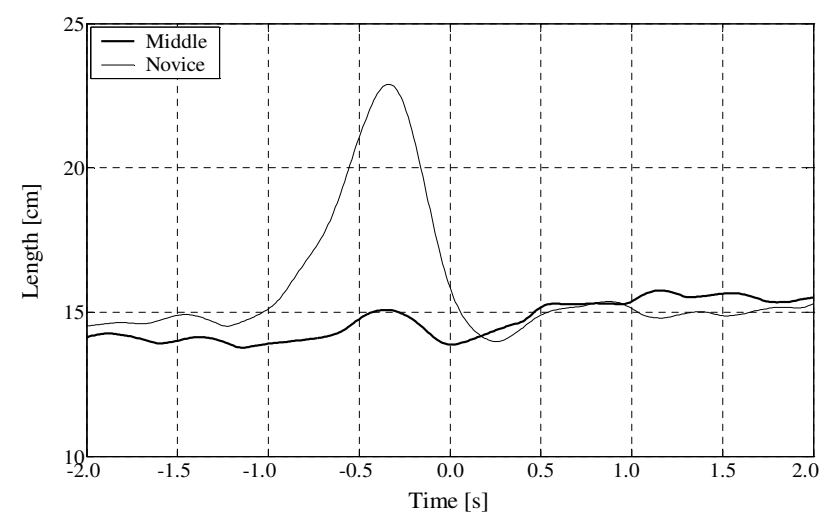

Fig. 9 Length between the grip end and the markers attached to the human body

\section{5. 実 験 結 果}

\section{$5 \cdot 1$ ゴルファーの身体とシャフト 間の距離}

インパクト前後 $2 \mathrm{~s}$ 間における経験者と未経験者のグリップエンドと身体間の距離変化を $l_{2}(t)$ を図 9 に示す. 両 者のインパクト前 $2 \mathrm{~s}$ のときの $l_{2}(t)$ は, 経験者 $14.1 \mathrm{~cm}$, 未経験者 $14.5 \mathrm{~cm}$ である . 両者ともに, アドレス時から トップオブスイングにかけて $l_{2}(t)$ は長くなり, トップオブスイングからインパクトにかけて , アドレス時の長さ へ戻るように減少している．インパクト近傍でアドレス時とほぼ同じ值となった．インパクトからフィニッシュに かけては正方向に増加し，フィニッシュで静止することで, $l_{2}(t)$ の変化も小さくなっている.この結果より, パッ ティング動作は単振子運動とは「似て非なるもの」である(9) ということが示された .

次に経験者と未経験者の比較を行う．経験者はインパクト前後の $l_{2}(t)$ の変化量は小さいのに対し，未経験者は 変化量が大きい. 特にアドレス時からインパクトにかけての変化量に大きな差がみられ, インパクト前までの変化 量の最大值は経験者 $1.3 \mathrm{~cm}$ ，未経験者 $8.4 \mathrm{~cm}$ であり，未経験者は経験者の約 6 倍であることが分かる．以上より， 経験者は一連のパッティング動作において , アドレス静止時の距離を維持しながら，パッティングしていること を確認した . 


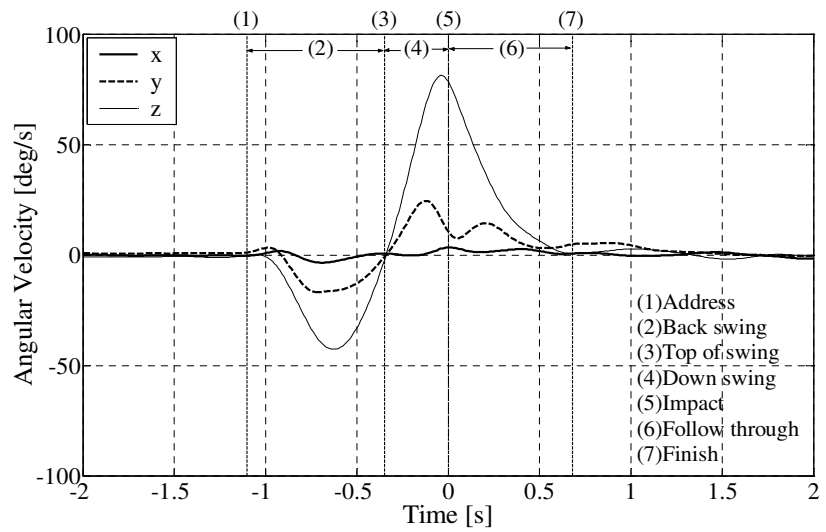

(a) Middle player

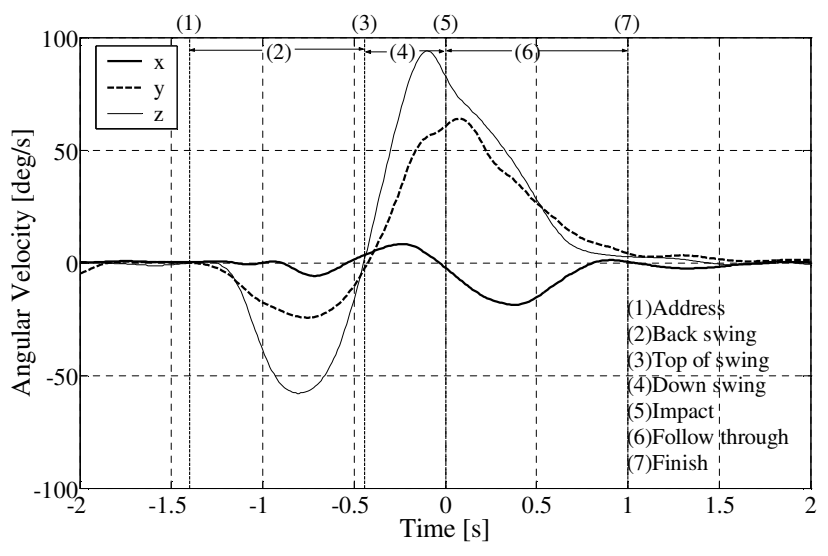

(b) Novice player

Fig. 10 Angular velocity in relative coordinate system

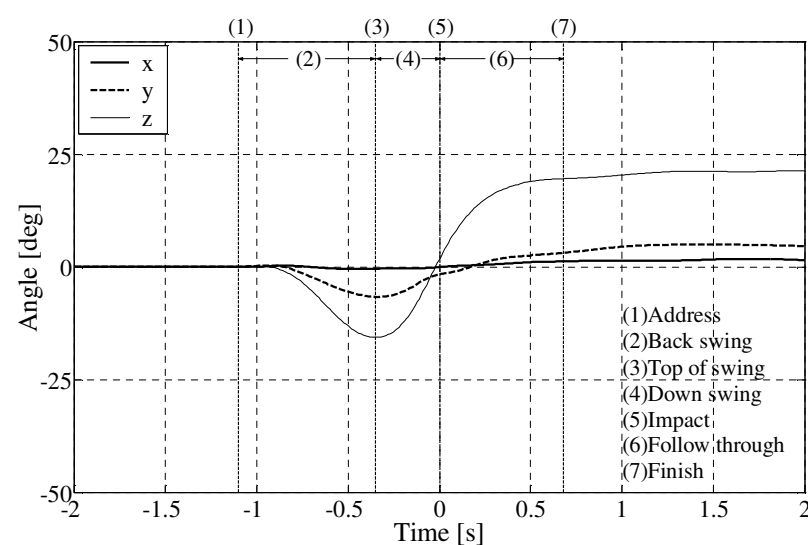

(a) Middle player

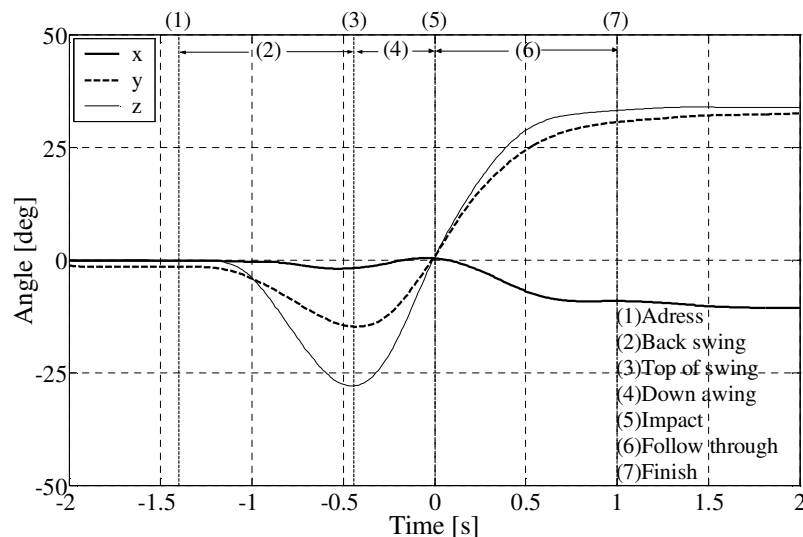

(b) Novice player

Fig. 11 Angle in relative coordinate system

\section{$5 \cdot 2$ 相対座標系の回転運動}

ボールがカップインしたときの相対座標系 $\mathrm{x}$ 軸, $\mathrm{y}$ 軸, $\mathrm{z}$ 軸周りの角速度を図 10 , 角度を図 11 を示す.なお, 各 図の (a) は経験者 , (b) は未経験者の結果を示す．

$\mathrm{x}$ 軸周り (図 10 および図 11 の太線) の回転運動は, パターヘッドのソール方向とトップ方向の回転運動に相当 し，計測結果の負方向がソール方向，正方向がトップ方向の回転運動を示す . 図 10(a) と図 11(a)より，経験者は (2) バックスイングで緩やかな角速度の変化がみられるが, 一連のスイングではほぼx 軸周りの回転運動を行って いないことがで確認できる .一方，図 10(b) と図 11(b) より，未経験者は (2) から (3) の区間で生じた x 軸周りの ヘッドの負方向 (ヘッドのソール方向)への姿勢を (3) から (4) の区間で正方向 (ヘッドのトップ方向)へ回転運動 することでアドレス静止時の姿勢に戻す状態にある . (5) インパクトでは, クラブヘッドがアドレス静止時に近い 姿勢となる．インパクト以降, ヘッドは (6) フォロースルー負方向 (ヘッドのソール方向)へ回転運動し，(7) フィ ニッシュで静止していることを確認できる．

$\mathrm{y}$ 軸周り (図 10 および図 11 の破線) の回転運動は, シャフトを回転軸とするクラブヘッドの回転運動に相当す る.この軸周りの回転運動は, インパクト後のボールの飛び出し方向を決定する運動要素の 1 つである. 静止し たボールに対して，インパクト近傍でのフェース面が絶対座標系 Z 軸と平行，およびX 軸と垂直な状態をスクェ アと呼ぶ . なお, 本研究でのへッドの初期状態はスクェアで, このときの絶対座標系 $\mathrm{Y}$ 軸周りの角度を $0 \circ$ とす る.また，初期状態に対し，インパクト近傍におけるフェース面が絶対座標系 Y 軸周り正方向の角度の姿勢をク ローズ , 負方向の角度の姿勢をオープンと呼ぶ . スイング開始から (3) トップオブスイングまで負方向への回転運 動を行っており，経験者に比べ未経験者の回転運動は大きい，弚のため，(3) トップオブスイングから (5) インパ クトの間で, 未経験者は速い角速度でアドレス静止のヘッドの状態，すなわちスクェアに戻す樣子が確認される . 


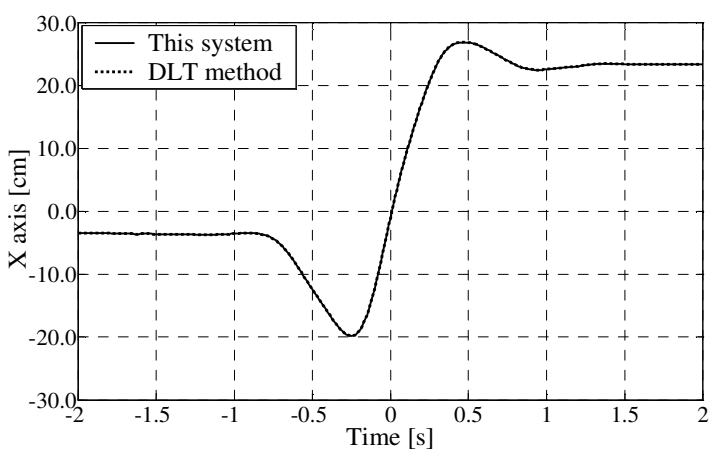

(a) $\mathrm{X}$ axis

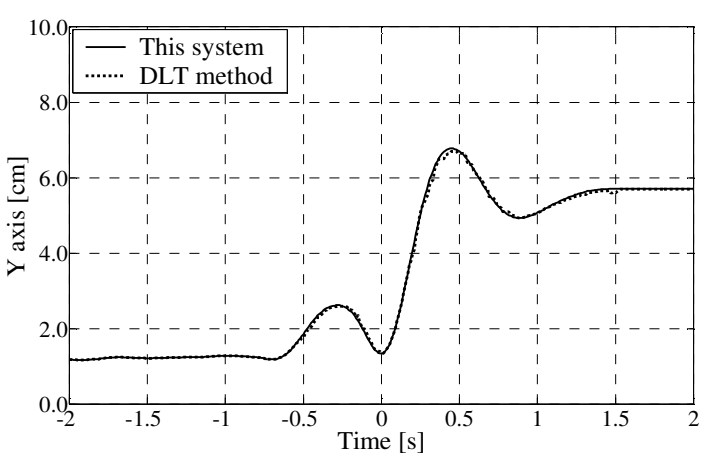

(b) $\mathrm{Y}$ axis

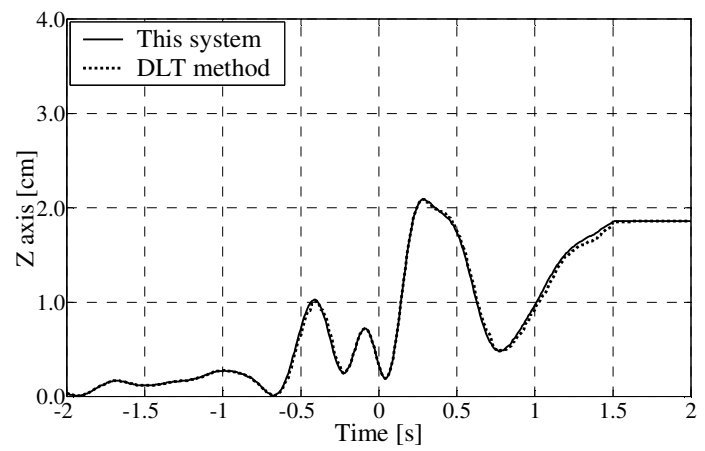

(c) $\mathrm{Z}$ axis

Fig. 12 Comparison with the suggested method and the DLT method

(4) ダウンスイングのインパクト前 0.2 秒付近まで両被験者ともに角速度と角度は増加傾向，すなわち正方向への 回転運動を行っている.しかし，インパクト近傍 (-0.1 秒から 0.1 秒の間) で比較すると未経験者は (4) ダウンスイ ングのインパクト前 0.2 秒付近までと同樣な回転運動を行っているのに対し, 経験者の角速度は減少し, 角度変化 も小さい傾向にあった .これらの結果から，パッティング動作中，経験者は $\mathrm{y}$ 軸周りの回転運動を小さく，フェー ス面をスクエアにしてボールをカップの方向に打っていることが示唆される .

$\mathrm{z}$ 軸周り (図 10 および図 11 の細線) の回転運動は, パターヘッドのフェース方向とバックフェース方向の回転 運動に相当し, 計測結果の負方向がバックフェース方向，正方向がフェース方向の回転運動を示す . スイング開始 から (5) インパクトの間, 経験者に比ベ未経験者の負方向 , すなわちバックフェース方向の回転運動が大きい傾向 にあった .さらに , (3) トップオブスイングでの回転角度は経験者に比へ， 2 倍程度大きな值であった . 目視であ るが，インパクト直後のボール速度は経験者に比べ未経験者のほうが速い傾向にあった．また，インパクト後の ボールの静止位置を比較すると，経験者の場合カップインを含めカップ付近 $(300 \mathrm{~cm})$ に集中して静止したのに対 し，未経験者は練習用マット $(348 \mathrm{~cm})$ を超えたり，カップの手前で停止する傾向にあった .

\section{$5 \cdot 3$ 絶対座標系でのクラブヘッドの変位と軌跡}

ヘッドの X , Y , Z 軸方向の変位を本論で提案した方法と DLT 法で求めた結果を比較する . 結果の一例を図 12 に示す.スイング開始からインパクトの区間において, DLT 法で求めた変位に対し本方法で求めた変位は, 各軸 方向ともに最大 $4.6 \%$ 程度の差が生じた .一方，インパクトからフィニッシュの区間において, DLT 法で求めた結 果に対し本方法で求めた変位は，X, $\mathrm{X}$ 軸方向で最大 $5.8 \%, \mathrm{Z}$ 軸方向で最大 $11.5 \%$ であり，これらの差はフィニッ シュ近傍で発生した . 図 5 で示すようにジャイロで生じたドリフトの影響があったと考えられる .

以上より, 計測時間に制限はあるが, 本論で提案した方法で求まるスイング開始からインパクト近傍までの変 位は，定量的評価を行ううえで十分な精度をもつ。

ボールがカップインしたときのクラブヘッドの絶対座標系 X 軸, Y 軸, Z 軸方向弚れ光れの変位を図 13 に示す . (a) は経験者, (b) は未経験者の結果であり, 各図の上段は X 軸方向, 中段は $\mathrm{Y}$ 軸方向, 下段は $\mathrm{Z}$ 軸方向の変位で ある。 


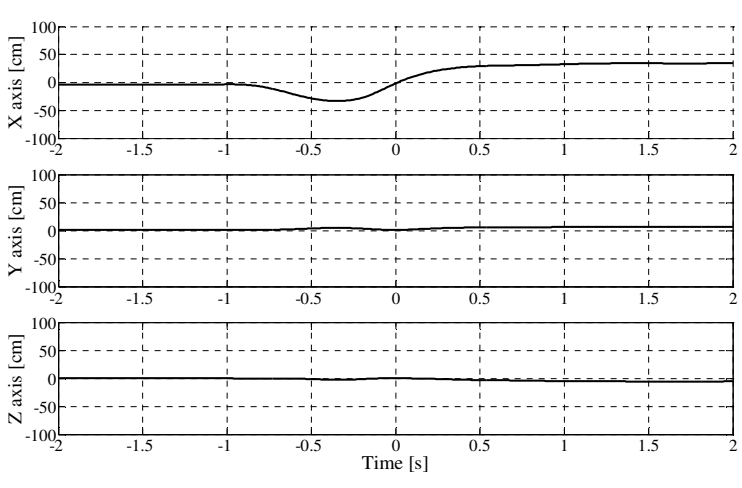

(a) Middle player
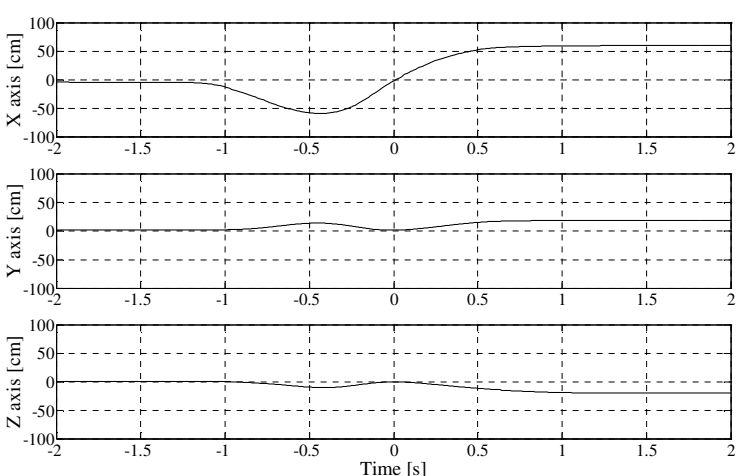

(b) Novice player

Fig. 13 Displacement in absolute coordinate system

$\mathrm{X}$ 軸方向の変位を比較する . 経験者はトップオブスイングで約 $30 \mathrm{~cm}$, フィニッシュで約 $34 \mathrm{~cm}, \mathrm{X}$ 軸方向の変 化の幅は約 $64 \mathrm{~cm}$ であった . 未経験者はトップオブスイング, フィニッシュともに約 $60 \mathrm{~cm}$ であり，変化の幅は約 $120 \mathrm{~cm}$ であった．Y 軸方向の変位を比較する . 経験者はトップオブスイングで約 $5 \mathrm{~cm}$, フィニッシュで約 $7 \mathrm{~cm}$ で

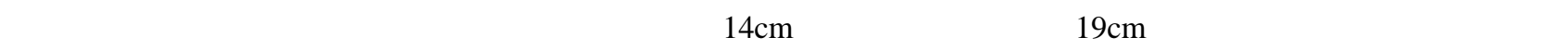
未経験者は経験者よりもへッドを高い位置まで上げる傾向にあった．Z 軸方向の変位を比較する . 経験者はほとん ど変化していない . 未経験者はインパクト前後で変化が表れており，インパクト前で約 $11 \mathrm{~cm} ，$ インパクト後て約 $19 \mathrm{~cm}$ の変化であった .

次に , ボールがカップインしたときの絶対座標系の各平面におけるクラブヘッドの軌跡を図 14 に示す . (a) は経 験者，(b) は未経験者の結果であり，各図の左上段は X-Y 平面，左下段は X-Z 平面，右段は Z-Y 平面上の軌跡で ある . 図中の太線で描かれた○印はボールの位置, 口印はアドレス時のフェース面の中心位置, 没印はインパク 卜時のフェース面の中心位置を示す . 経験者のアドレス静止時からトップオブスイングまでの区間とトップオブス イングからインパクトまでの区間の軌跡がほぼ一致しているのに対し, 未経験者の軌跡は一致していないことが 確認できる . また , X-Z 平面におけるX X 軸の範囲 $-20 \mathrm{~cm}$ から $20 \mathrm{~cm}$ の間での軌跡を比較すると，経験者はほぼ直 線運動であることが確認できる .これらの違いは, 図 9 の「ゴルファーの身体とシャフト間の距離の変化量」と 図 11 の「角度の変化量」の違いで生じたものである。

\section{6. パットスキルの定量的評価の可能性}

著名なパッティングの指導書 ${ }^{(1)}$ では , パッティング動作時のヘッドの軌跡やインパクト瞬間の静止したボールに 対するヘッドのフェース角度が重要である，と言語表現されている . 例として , 一連のパッティング動作時の $2 つ$ の規範を示す．

（1）フェース角度については常に目標ラインに対してスクェアの状態を保ちながらスイングする .

(2) ヘッドの軌跡については目標ラインに沿って真っ直ぐ, 正確にスイングする .

(1)の規範を定量的に評価するために , 図 11 のインパクト瞬間の $\mathrm{y}$ 軸周り角度を用いる . 経験者の角度は約 -1

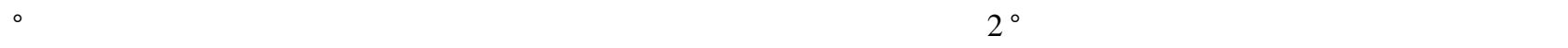
この結果から，経験者のフェース角度はスクェアに近い状態でボールを打っていることか確認される．よって，イ ンパクト瞬間の y 軸周り角度を比較することで, (1)の規範は定量化できたといえる．

(2)の規範を定量的に評価するために, 図 13 のZ軸方向の変位を用いるが，ここではインパクト前後 0.1 秒間に おけるZ Z軸方向の変位 (図 15) で評価する . 図 15 の時間において , 経験者の Z 軸方向のヘッド運動は - $1 \mathrm{~cm}$ から $1 \mathrm{~cm}$ の範囲，未経験者の運動は - $2 \mathrm{~cm}$ から $2 \mathrm{~cm}$ の範囲で行われていることか確認される．さらに，未経験者の波 形は上に凸の放物線の傾向にあるのに対し，経験者の波形は直線に近い傾向にあることが確認される．よって，Z 軸方向の変位を比較することで, (2)の規範は定量化できたといえる .

以上 , 提案するシステムで計測および推定 (計算)されたゴルフパッティング動作にともなうクラブヘッドの運 動データは, ゴルフの指導書で言語表現された規範を定量化できる可能性を示している． 


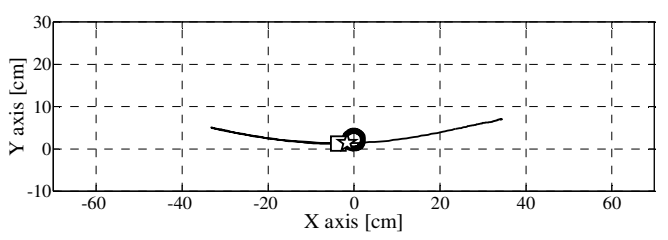

The direction of the front

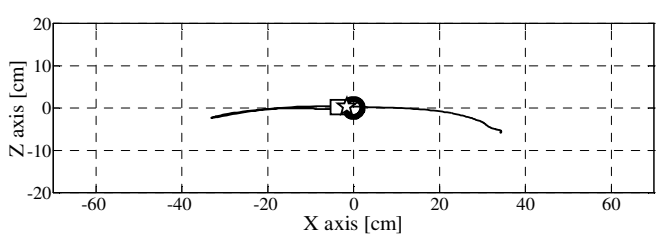

The direction of the vertical

(a) Middle player

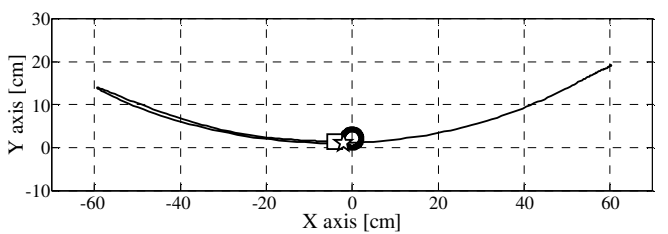

The direction of the front

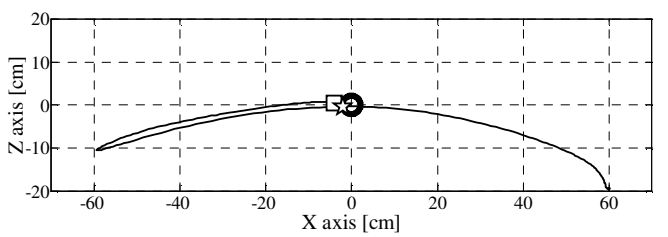

The direction of the vertical

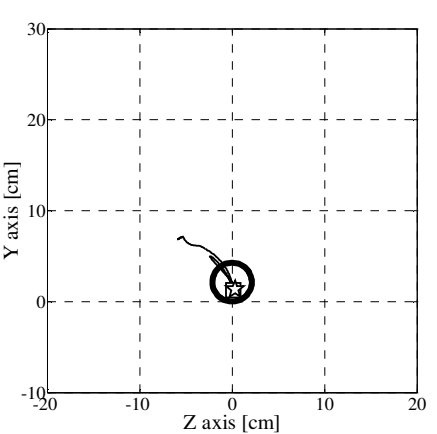

The direction of the horizon

(b) Novice player

Fig. 14 Locus in absolute coordinate system

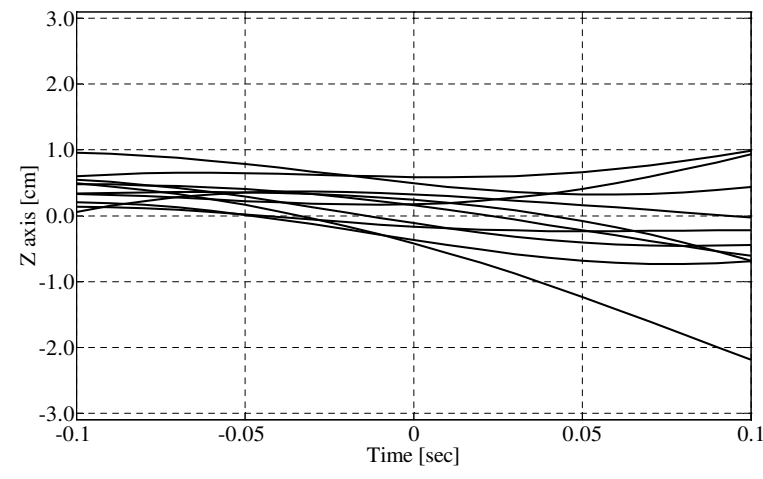

(a) Middle player

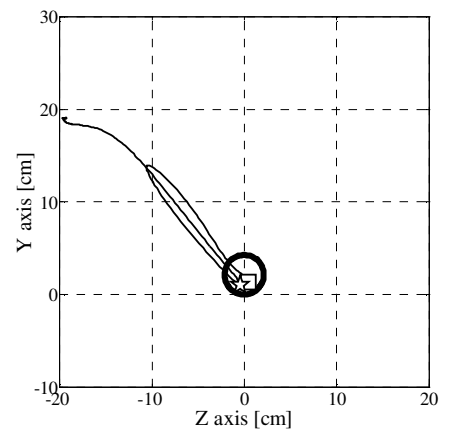

The direction of the horizon

Fig. 15 Comparison of the club head locus near impact

\section{7.おわりに}

本論では , ジャイロセンサと赤外線センサを使用した三次元空間内におけるパッティング動作時のクラブヘッド 運動の計測方法を提案し，弚のシステム化について取り組んだ . 具体的に次の項目に取り組んだ .

(1) 静止したボールと地面との接点を原点とする絶対座標系, アドレスした際のシャフト延長線とゴルファーの 脊髄を結んだ線上にある身体との接触点 (腹部) を原点とする相対座標系を定義し，新たなパッティングモデ ルを提案した . 
(2) (1)のモデルから三次元空間内のクラブヘッドの変位と軌跡を計測するための方法を提案した .

（3）（2）の計測方法をシステム化した .このシステムを用いて，実際のパッティング動作を計測し，光の結果につ いて述べた .

(4) 言語表現されているパッティング動作に関するいくつかの規範を定量化することで, 本計測方法とシステム の有用性について示した .

これらの結果より，ゴルフのパッティング動作におけるクラブヘッド運動の簡易計測システムが示された . ま た , パットスキル評価を定量化できる可能性も示された . パットスキルの定量化は興味ある課題であり，今後の研 究課題である.

文献

(1) Pelz D., Dave Pelz's putting bible:the complete guide to mastering the green (2000), pp. 1-60, New York, Knopf Doubleday Publishing Group.

(2) Delay D., Nougier V., Orliaguet P. and Coello Y.," Movement control in golf putting " , Human Movement Science, Vol. 16, No. 5 (1997), pp. 597-619.

(3) Sim M. and Kim U.," Differences between experts and novices in kinematics and accuracy of golf putting " , Human Movement Science, Vol. 29, No. 6 (2010), pp. 932-946.

(4) 池上康男, 桜井伸二, 矢部京之助“; DLT 法”, Japan Journal of Sports Science, Vol. 10, No. 3 (1991), pp. 191-195.

(5) 大串哲朗, 尾崎宏樹, 佐久間馨, 丸山岡生“, パッティング動作におけるアドレス, インパクト時のパターフェースアングル に関する一考察”, 上智大学体育, No. 41 (2008), pp. 45-52.

(6) 平井隆之, 岩惪卓三, 長谷川宏, 大貫正秀“, 安定性の良いパタークラブの推定に関する研究”, 日本機械学会ジョイント・ シンポジウム講演論文集:スポーツ工学シンポジウム:シンポジウム:ヒューマン・ダイナミックス 2009, pp. 7-12.

(7) Lee D., Ishikura T., Keel S., Gonzalez D. and Passmore S.,, Head - Putter coordination patterns in expert and less skilled Golfers”, Journal of Motor Behavior, Vol. 40, No. 4 (2008a), pp. 267-272.

(8) 石倉忠夫“" ゴルフ・パッティングの学習初期における頭-パター間の協応パターンの変化-事例的研究”, 同志社スポーツ 健康科学, No. 3 (2011), pp. 47-55.

（9）野澤むつこ, 新井哲平, 田中克昌, 須田和裕“, 物理振り子とパッティング動作の比較”, 日本機械学会ジョイント・シンポ ジウム講演論文集:スポーツ工学シンポジウム:シンポジウム:ヒューマン・ダイナミックス 2006, pp.181-185.

(10) Kevin K., Yoon W., Perkins C. and Najafi K., Wireless MEMS inertial sensor system for golf swing dynamics " , Sensors and Actuators, A 141 (2008), pp.619-630.

(11) Watanabe K. and Hokari M.," Kinematical analysis and measurement of sports form " , Systems, Man and Cybernetics, Part A: Systems and Humans, IEEE Transactions, Vol. 36. Issue 3 (2006), pp.549-557.

(12) 大貫正秀, 白井良明, 島田伸敬, 植田勝彦“, ゴルフスイング自動診断システムの開発” , 日本機械学会ジョイント・シンポ ジウム講演論文集:スポーツ工学シンポジウム:シンポジウム: ヒューマン・ダイナミックス 2010, pp.333-337.

(13) 穂苅真樹, 土岐仁, 鳴尾丈司, 蘆田浩規“, ゴルフクラブスイング時の身体回転運動の計測とスキル評価”, 日本機械学会論 文集 C 編, Vol.72, No.715 (2006), pp. 850-856.

(14) Watanabe K. and Hokari M.," Measurement of 3-D Loci and Attitudes of the Golf Driver Head while Swinging " , Systems, Man and Cybernetics, Part A: Systems and Humans, IEEE Transactions, Vol. 36. Issue 6 (2006), pp.1161-1169.

(15) Fairweather M., Button C. and Rae I.," A critical examination of motor control and transfer issues in putting " , Science and Golf IV: Proceedings of the World Scientific Congress of Golf (2002), pp. 100-112. 